\title{
The last alien reaching Sicily: Isognomon legumen (Gmelin, I79 I) (Mollusca Bivalvia Isognomonidae)
}

\author{
Danilo Scuderi' \& Alfio Viola²
}

${ }^{1}$ I.I.S.S. “E. Majorana”, via L. Capuana 36, 95048 Scordia, Catania, Italy: danscu@tin.it

${ }^{2}$ Dipartimento di Scienze Biologiche, Geologiche ed Ambientali, Sezione di Scienze della Terra, Palazzo Ramondetta, Corso Italia 57, Catania, Italy; e-mail: aviola@unict.it

\begin{abstract}
The finding of some living specimens of an alien bivalve of the genus Isognomon Lightfoot, 1786 (Mollusca Bivalvia Isognomonidae) attached to rocks is here reported in Sicily for the first time. This is the last of a series of numerous finding of alien molluscs reports in the same area, for which a human-mediated model was supposed. An attempt to indicate the age of the specimens are here furnished on the basis of the number of byssus filaments. Some further environmental notes underline how in recent times these alien species seem better integrated inside the indigenous benthic communities in the Southern Mediterranean coasts, being better allowed in the first settlement by the recent climatic changes and resulting ecologically well organized and structured as in the tropical environments of provenance.
\end{abstract}

KEY WORDS Alien species; Mediterranean; invasive species; Sicily; Bivalves; Mollusca; Isognomon.

Received 13.09.2019; accepted 21.11.2019; published online 11.12.2019

\section{INTRODUCTION}

Due to the high increased number of alien species signalled in the Mediterranean Sea, in the last decades the tropicalization in marine environments seem to be a process less ethereal and more real than in the recent past. Findings of non-indigenous mollusc species, like Pinctada radiata (Leach, 1814), started just after the Suez Canal aperture (Monterosato, 1878). Nowadays, numerous records concern in particular the eastern regions of the Mediterranean, i.e., Lebanon, Israel, Turkey, Cyprus or Egypt, being the first landing places for newcomer molluscs from the Red Sea. Another different way is the human-mediated invasions, which seem to justify too rapid spreadings of alien species in those regions far from the main Mediterranean entrances. Among the latter, many are due to ballast waters of ships, whose traffic is more increased today (Zibrowius, 1992).

In the Mediterranean Sea two species of Isognomon Lightfoot, 1786 (Mollusca Bivalvia Isognomonidae) are reported: I. legumen (Gmelin, 1791), which was firstly recorded and reported by Mienis et al. (2016) from Israel, and I. australica (Reeve, 1858), reported by Angelidis \& Polyzoulis (2018) from Greece only in very recent times.

Despite its recent penetration, I. legumen seems on the contrary well distributed in the Mediterranean Sea considering all the official records reported and those which could instead be considered misidentifications with other species, i.e., Malleus regula (Forsskål in Niebuhr, 1775) (Bivalvia Malleidae) (see for instances Crocetta, et al., 2017, and Stamouli et al., 2017, Crocetta, 2018). 
In Sicily, findings of human-mediated alien species have considerably intensified in these last two decades, with records of species which often have been well established. The last in order of time is Lottia sp. (Scuderi \& Eernisse, 2016), whose complete identification and origin are still under study.

The discovery of seven living specimens and a shell of the Bivalve I. legumen further updates the number of alien species in central Mediterranean, adding new informations on the invasion modalities and possibilities of establishment success of the species inside the basin. This renovate the invocation to pay higher attention to ballast water, whose management in Mediterranean Sea and not Mediterranean harbours should be regulated through stricter lows, which allowed limitations on the spreading of alloctons to different geographic sites.

ABBREVIATIONS AND ACRONYMS. h: height; spec.: living specimens; sh.: shell/shells; st.: station; AGC: Alfio Germanà collection (Catania, Italy); PMC: Pasquale Micali collection (Fano, Pesaro-Urbino, Italy); DSC: Danilo Scuderi collection (Scordia, Catania, Italy).

\section{MATERIAL AND METHODS}

The finding of a single specimen of I. legumen along the rocky shores of Catania, eastern Sicily (Fig. 1) in August 15, 2017 was rather fortuitous, since it lied unattached on the rocky bottom at $-1.5 / 2 \mathrm{~m}$ depth. Probably during the night, fishes feed on the mussel layer and detached it from the rocks. Two thorough samplings lead to the finding of other four spec. in the same season, which were handily removed from the rocky substrates, at -1 to $-4 \mathrm{~m}$ depth. In summer (July/August) 2018 and 2019 four more specimens were collected. In the same area and conditions in addition a complete sh. was found among shell grit at $-2 \mathrm{~m}$ depth.

Shells were measured for morphological analysis and the soft body was removed from each specimen's shell and preserved in $90^{\circ}$ ethanol for future molecular analysis. Observations were conducted with a stereoscope and photographs and drawings documented the collected specimens.

The Sicilian material was compared to specimens collected in the Persian Gulf (PMC) and to specimens of I. australica from Karpatos, Greece,

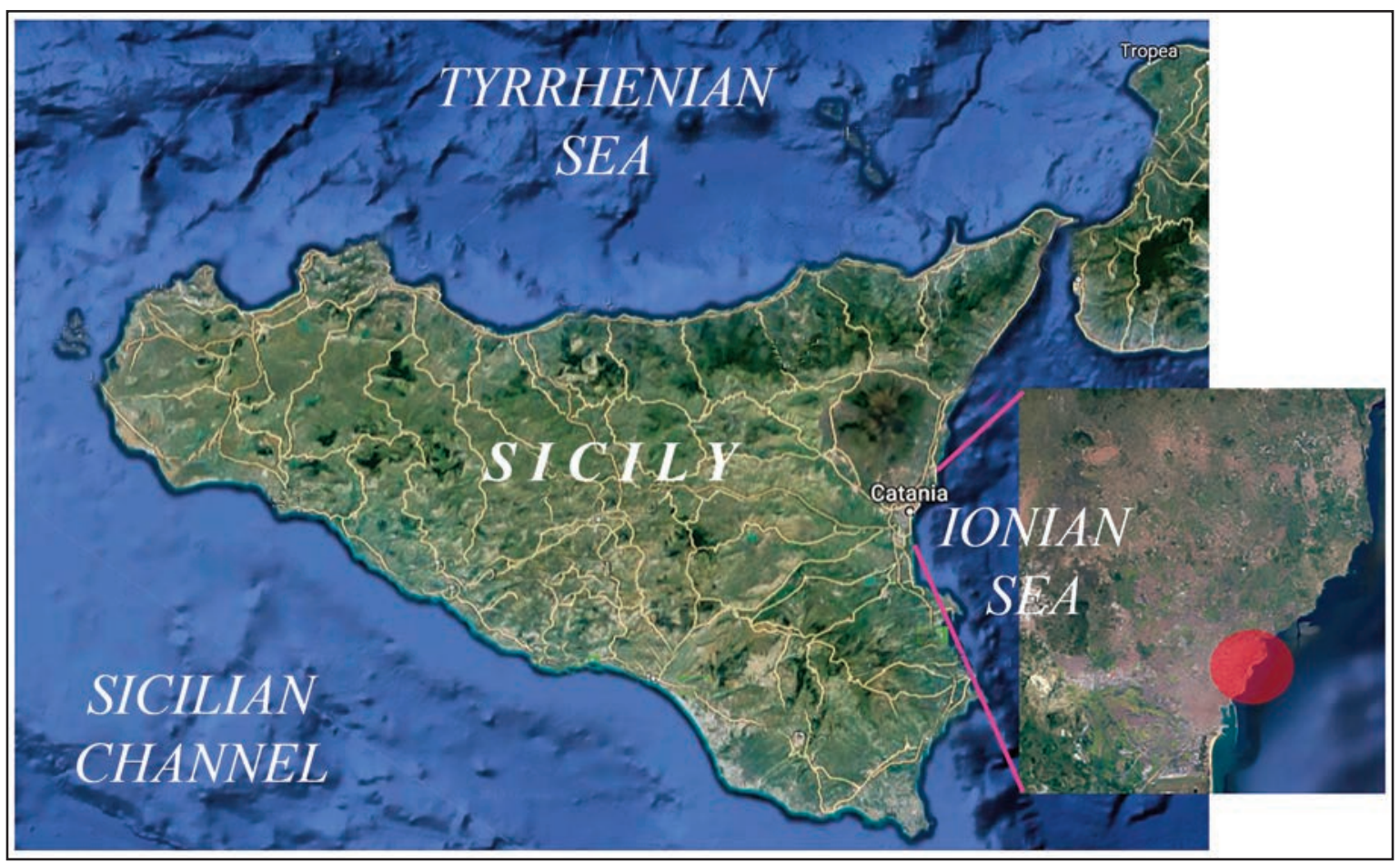

Figure 1. Map illustrating the collecting locality of Isognomon legumen in eastern Sicily (red spot). 


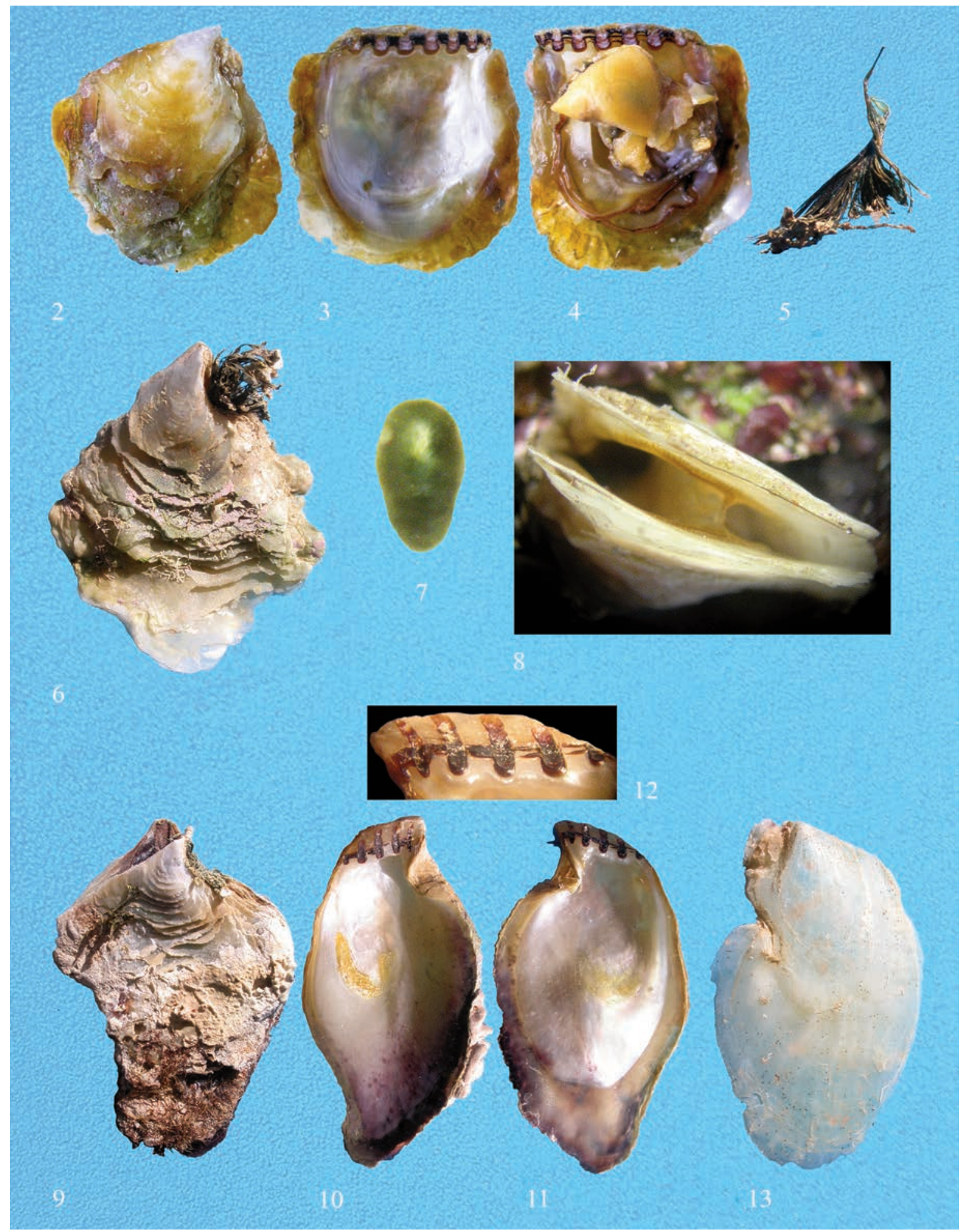

Figures 2-7. Isognomon legumen. Fig. 2: A specimen in upper view, Catania, eastern Sicily, h: 1.4 mm. Fig. 3, internal side of the left valve. Fig. 4: internal side of the right valve. Fig. 5: byssus. Fig. 6: specimen from Catania in upper view, h: 22.1 $\mathrm{mm}$. Fig. 7: a pearl from a specimen from Catania, h: $1.2 \mathrm{~mm}$. Figure 8. A living specimen in aquarium from Catania, h: $20.2 \mathrm{~mm}$. Figures 9-12. Two specimens from Abu Dhabi, Persian Gulf, in upper and internal view with detail of the ligament, h: 31.2 and $42.0 \mathrm{~mm}$ respectively. Fig. 13. Isognomon australica, Karpatos, Greece, h: $3.4 \mathrm{~mm}$. 
at $-38 \mathrm{~m}$ depth, found in september/2017 (AGC) for supporting the morphological determination.

\section{RESULTS}

\section{Systematics}

Classis BIVALVIA Linnaeus, 1758

Ordo OSTREIDA Férussac, 1822

Superfamilia PTERIOIDEA Gray, 1847

Familia ISOGNOMONIDAE Woodring, 1925

Genus Isognomon Lightfoot, 1786

Type species: Isognomon perna (Linnaeus, 1767)

Isognomon legumen (Gmelin, 1791) (Figs. 2-12)

EXAMINED MATERIAL. Italy, Catania, eastern coast of Sicily, $9 \mathrm{spec}$. and $1 \mathrm{sh}$. along the northern rocky shore of the city, $-1 / 4 \mathrm{~m}$ depth (DSC). Four sh. of I. legumen from Abu Dhabi, United Arab Emirates (UAE), Persian Gulf, -3/6 m (PMC).

DESCRIPTION. Specimens collected were assigned to Isognomon on the basis of the characteristic "denticulate" ligament, being the hinge straight and edentulous (Figs. 3, 4 and 10-12). The height of specimens varies from 22.6 to $14.8 \mathrm{~mm}$. Valves (Figs. 2-12) are variable in form, relatively solid and moderately convex, rounded at margins except the upper side, which is straight, with a pointed laterally placed umbo; they are ornamented by marked and fragile laminate processes, smooth and nacreous on the internal side (Figs. 2, 4 and 10,11) and white-greenish in colour on the external side, with orange/yellowish periostracum.

Soft parts (Figs. 4 and 8) are pale green-yellowish with orange edges and gill tips of the mantle; gonad is almost egg-yellow. Byssus is constituted by numerous not very long green filaments (Fig. 5).

A single drop-shaped olive-green pearl (Fig. 7) $1.2 \mathrm{~mm}$ high has been found inside a specimen.

Specimens from the Persian Gulf (Figs. 9-12) were thicker and higher, reaching $40.22 \mathrm{~mm}$, but substantially with the same morphological characteristics.

Distribution and Biology. Specimens collected in eastern Sicily were attached with the byssus to epibionts living on the volcanic substratum, among the trottoir constituted by other molluscs, many of which were alien too, and red calcareous algae present in the subtidal zone. Other species present were: Brachidontes pharaonis (P. Fischer, 1870), Pinctada radiata (Leach, 1814), Ostrea stentina Payraudeau, 1826, Anomia ephippium Linnaeus, 1758, Mytylus galloprovincialis Lamarck, 1819, Aplysia dactylomela Rang, 1828.

Apart the first almost fortuitus record, among the algal turf and between the other epibionts present and constituting a trottoir, specimens live collected were easily detectable by the yellowish mantle seen between opened valves.

REMARKS. Isognomon legumen was often misidentified with Malleus regula (Crocetta, 2018), from which could be easily distinguished by the edentuous hinge in which 5-6 peculiar resilifer bearing the ligament are present (Fig. 12). Being recently penetrated in the Mediterranean, I australica (Fig. 13) is the most similar species in this basin. This latter has flat, almost smooth, except for some faint and flat axial ridges, fragile and semitransparent valves, which make the species distinguishable from I. legumen. Moreover, the niche they prefer is different: specimens of I. australica were collected attached with byssus under stones in the upper infralittoral zone, preferring a slightly deeper fringe (Angelidis \& Polyzoulis, 2018 and Micali pers. comm. feb/2019).

\section{DISCUSSION AND CONCLUSIONS}

Harper \& Morton (1994) reported the species reaching a probable age of a couple of years, which is therefore quick in growing, the age being probably correlated to the number of filaments of the byssus as suggested by the same Authors. Sexual maturity seem reached just in specimens of 6 mm (Harper \& Morton, 1994): so all the Sicilian specimens were mature. They reported the most frequent height of studied material around $50 \mathrm{~mm}$ (Harper \& Morton, 1994, fig. 6), while an adult specimen of $14.4 \mathrm{~mm}$ showed a byssus constituted by 42 filaments. The maximum height reached by specimens here studied was $22.6 \mathrm{~mm}$, with a cone of byssus constituted by almost 150 filaments, 
thus resulting almost full grown, though smaller in dimensions, and probably settled two years before.

This observations place chronologically the Sicilian record approximately at the same time with that of Israel (Mienis et al., 2016), which is the first for the Mediterranean Sea. Putting all these facts together, we can say that, while the Israeli population of I. legumen probably arrived from the Suez Canal, a human-mediated mode of invasion of the Sicilian specimens is the most probable explanation.

In Stamouli et al. (2017), Ovalis and Zenetos reported the finding of fourteen specimens of I. legumen in Dalyan, Iztuzu, and southern Turkey, but the specimen in figure 20, p. 548 , is instead I. australica. Judging by the reported geographical distribution Micali et al. (2017) consider I. legumen and I. australica as synonyms.

Some final considerations should be done on the ecological conditions in which I. legumen was found in Sicily. In fact, the structure of the biofouling community living on a Pinctada bed in the Red Sea described by Wronski (2010) are similar to that of the Sicilian hard substrate community found in some locality. In particular, actual chemical-fisical parameters in terms of water (surface temperature, salinity) in eastern Sicily during the late spring and summer seasons (pers. obs.) are similar to those reported by this last Author for the Red Sea, although high seasonal excursions persist in Mediterranean temperate localities. Once entered the Mediterranean, the same species seem to aggregate together to maintain the same structure of tropical community. Surprisingly, as personally observed, some species like Pinctada radiata, long time after the first invasion of a certain area, tend to form a more complex structure of numerous specimens attached to each other and to aliens of different species merging together and forming tropicallike enclaves similar in structure to those described for the Red Sea (Wronski, 2010). These "pseudo-tropical" structures seem subjected to annual fluctuations and in some years they appear less structured than in other years.

The regular finding of specimens of I. legumen, though never abundant, during these last three years seem to confirm the consolidation of the Sicilian population of this species.

\section{ACKNOWLEDGENENTS}

This research was sponsored by the 'Città Metropolitana di Messina' the official management body of the reserve (permission no. 557/VIII DIR, 12.03.2014). Facilities were provided by the mussel farm FARAU s.r.1.

\section{REFERENCES}

Angelidis A. \& Polyzoulis G., 2018. New Distributional Records of Four Indo-Pacific Species from Astypalaia Island, South Aegean Sea, Greece. Xenophora Taxonomy, 21: 3-10.

Crocetta F., 2018. Malleus regula in Libya: another case of misidentification for Isognomon legumen. Triton, 37: 4-5.

Crocetta F., Gofas S., Salas C., Tringali L.P. \& Zenetos A., 2017. Local ecological knowledge versus published literature: a review of non-indigenous Mollusca in Greek marine waters. Aquatic Invasions, 12: 415-434. https://doi.org/10.3391/ai.2017.12.4.01

Harper E.M. \& Morton B., 1994. The biology of Isognomon legumen (Gmelin, 1791) (Bivalvia: Pterioida) at Cape d'Aguilar. Hong Kong, with special reference to predation by muricids. In: Morton B.B. (Ed.), The malacofauna of Hong Kong and Southern China, III, Proceedings of the Third International Workshop on the Malacofauna of Hong Kong and Southern China, Hong Kong 1992, Hong Kong University Press, 405425.

Micali P., Siragusa F., Agamennone F., Germanà A. \& Sbrana C., 2017. Karpathos Island (Greece) and its Indo-Pacific alien species. Part 1. Bollettino Malacologico, 53: 40-49.

Mienis H.K., Rittner O., Shefer S., Feldstein T. \& Yahel R., 2016. First record of the Indo-Pacific Isognomon legumen from the Mediterranean coast of Israel (Mollusca, Bivalvia, Isognomonidae). Triton, 33: 9-11.

Monterosato di T.A., 1878. Enumerazione e sinonima delle conchiglie Mediterranee. Giornale di Scienze Naturali ed Economiche in Palermo, 13: 61-115.

Scuderi D. \& Eernisse D.J., 2016. A new alien limpet for the Mediterranean sea: Lottia sp. (Patellogastropoda Lottiidae). Biodiversity Journal, 7: 287-293.

Stamouli C., Akel E.H.Kh., Azzurro E., Bakiu R., Bas A.A., Bitar G., Boyaci Y.Ö., Cakalli M., CorsiniFoka M., Crocetta F., Dragičević B., Dulčić J., Durucan F., El Zrelli R., Erguden D., Filiz H., Giardina F., Giovos I., Gönülal O., Hemida F., Kassar A., Kondylatos G., Macali A., Mancini E., Ovalis P., Paladini de Mendoza F., Pavičić M., Rabaoui L., Rizkalla S.I., Tiralongo F., Turan C., Vrdoljak D., 
Yapici S. \& Zenetos A., 2017. New Mediterranean Biodiversity Records (December 2017). Mediterranean Marine Science, 18: 534-556. http://dx.doi. org/10.12681/mms. 15823

Wronski T., 2010. The molluscan bio-fouling community on the Red Sea pearl oyster beds (Mollusca: Pteriidae). Zoology in the Middle East, 51: 67-73.

Zibrowius H., 1992. Ongoing modifications on the Mediterranean marine fauna and flora by the establishment of exotic species. Mesogée, 51: 83-107. 